\title{
IN THE CLOSE ENCOUNTER BETWEEN ART PRACTICE AUTOETHNOGRAPHY: THE FIGURES OF DISPLACEMENT IN CONTEMPORARY ART
}

\author{
Asc. Prof. Dr. H. Esra OSKAY MALİCKİ \\ Ankara Hacı Bayram Veli University, Turkey \\ harika.oskay@hbv.edu.tr \\ https://orcid.org/0000-0001-6684-4204
}

\begin{abstract}
The shifting position of the artist in the field of cultural inquiry in parallel with the emphasis on subjective truth replacing the objective basis in ethnographic research opens a shared ground for discussions between ethnography and art. Focusing on representations of displacement in contemporary art practice, the paper aims to understand different modalities of representing experience through studying the subjective responses of selected artists in the framework of ethnographic turn in art. The paper traces the figures of displacement within contemporary art criticism in parallel with the figurative language of contemporary social thought that manifests a thinking through spatial metaphors. In this regard, the cross field between ethnography and autoethnography in particular in relation to art practice is analyzed through case studies, in order to expand the interdisciplinary dialogue between these two distinctive forms of cultural inquiry. Instead of seeking methodological analogies between ethnography and art practice, the study focuses on this particular motivation of ethnographic work to capture reality and express experience. Beyond the mere replication of ethnographic methods that risks producing meagre ethnographies and restricting the emergence of possibilities across the distinctive practices of inquiry, the paper aims to locate the conversation between art and autoethnography on a transdisciplinary ground. In this way, the research strives to shift the focus from methodological disparities and mimicries towards the shared concerns of art and ethnography.
\end{abstract}

Keywords: Ethnographic Turn in Art, Autoethnography, Displacement, Home.

\section{OTOETNOGRAFI VE SANAT PRATIIĞININ YAKIN TEMASINDA ÇAĞDAȘ SANATTA YERINDEN EDİLME FİGÜRLERİ}

\section{ÖZ}

Sanat ve etnografi arasındaki ara alan, kültürel araştırmanın alanına kayan günümüz sanatçısının pozisyonu ve etnografik araştırmada nesnel yaklaşımların yerini hakikatin öznelliğine yapılan vurguyla ortak bir zemine açılır. Yerinden edilme figürlerinin günümüz sanatındaki temsillerine odaklanan bu makale, deneyimin farklı temsil biçimlerini seçilen sanatçıların öznel yaklaşımlarını inceleyerek anlamayı amaçlar. Çağdaş sanat eleştirisinde sıklıkla karşımıza çıkan yerinden edilme figürlerini çağdaş sosyal teorinin mekansal metaforlarla düşünen yaklaşımına parallel bir şekilde izler. $\mathrm{Bu}$ anlamda, etnografinin ve özellikle otoetnografinin sanat pratiği ile olan ilişkisi disiplinlerarası diyalogu genişletmek için örneklerle analiz edilerek genişletilmeye çalışılmıştır. Çalışma, sanat pratiği ve etnografi arasında metoolojik yakınlıklar aramaktansa etnografik yöntemin gerçekliği yakalama ve deneyimi ifade etme ödevi üzerine kurulur. Vasat etnografiler üreten ve farklı düşünme biçimleri arasında oluşabilecek olasılıkları sınırlayan etnografik metotların taklidi üzerine kurulu bir

Submit Date: 15.04.2019, Acceptance Date: 20.06.2019, DOI NO: 10.7456/10904100/002 
yöntemdense, makale etnografi ve sanat arasındaki diyaloğu transdisipliner bir zeminde tartışır. Böylece metodolojik ayrımları ve taklitleri bir kenara bırakarak sanat ve etnografi arasındaki ortak kaygilara odaklanır.

Anahtar Kelimeler: Sanatta Etnografik Dönüm, Otoetnografi, Yerinden Edilme, Ev.

\section{INTRODUCTION}

While the position of the researcher as a representative of objective truth becomes challenged as a consequence of epistemological shifts in humanities, so does the engaged artist's location and his/her role as a cultural producer. The subjective voices in the study of culture becomes a valid means of research, hence the researcher's self becomes a medium of inquiry and consequently bringing the endeavor of the artist's work closer to the researcher. This paper focuses on representations of displacement, a common research interest artists share with other researchers from the field of cultural studies. The figures of displacement within contemporary art criticism is analysed in parallel with the figurative language of contemporary social thought that manifests a thinking through spatial metaphors. As the paper proceeds towards understanding the cross field between art and social inquiry, the aim is to trace the art historical motivations behind this shift in art practice towards the non-art realms and inquires into the geneaology of ethnographic turn in relation to shifting meaning of space. Upon this ground the paper draws upon its main focus, the representations of displacement in art practice through case studies, and analyses individual voices reflecting on displacement in an autoethnographic manner. To this end, a close look into the artistic strategies in the works of Jonas Mekas, Marcel Duchamp, Mona Hatoum and Zarina Hashmi becomes a means to explore how the effects of displacement are represented in art practice, how the individual voices of the artists renders the experience of displacement. Through this method of case studies, the paper operates through the particularities of subjective voices characteristics of autoethnography instead of theory generating generalizations that renders individualities as representative of a wider order.

\section{THE FIGURES OF DISPLACEMENT IN CONTEMPORARY ART}

In his study The Ends of Exile art critic T.J. Demos analyses the variety of responses artists have given to the phenomenon of displacement across different periods (2009). Demos discusses figures of displacement as a state of mind, an ethical stance, a premise for "a politics of equality" in a world marked by uneven border traffic, by different orders of movement (2009: 87). In outlining the aesthetics of negotiating with the experience of movement, he identifies different ethical positions, different ways of dwelling in the world within the figures of diasporic, the nomad and the refugee. Each of these three figures mark a distinctive position taken against the reality of an increasingly precarious world defined by, "the diverse mobilities of peoples, objects, images, information and wastes; and of the complex interdependencies between, and social consequences of, these diverse mobilities" (Urry, 2000: 1). Thus, the flux of people and their material world infiltrates into the language of how we perceive the world. In this regard, Demos' delineation of the figures of exile diasporic, refugee, flaneur etc. echoes the figurative language of contemporary social thought that is inclined to think with spatial metaphors, with different modalities of inhabiting space defined by movement. The field of displacement is measured in the footsteps of the figures of displacement.

A related vocabulary also appears in the analyses of other art critics such as Saloni Mathur. Marsha Meskimmon, and Nikos Papastergiadis. Mathur announces the coming of the time of the migrant, in The Migrant's Time: Rethinking Art History and Diaspora (2011), and Papastergiadis foresees the emergence of a "cosmopolitan disposition" (2011). Likewise, Meskimmon, in Contemporary Art and

Submit Date: 15.04.2019, Acceptance Date: 20.06.2019, DOI NO: 10.7456/10904100/002 
the Cosmopolitan Imagination sets out to survey, "the role of art in conceiving and reconfiguring the political, ethical and social landscape of our time" (2011: 6). She forecasts the emergence of a cosmopolitan identity: a "be(long)ing at home everywhere" (2011: 6). In this regard, art not only represents and interprets this unsteady state determined by diverse mobilities unsettling the secure boundaries of our abodes now but, as Meskimmon argues, art has an agency that, "enable[s] us to participate in, and potentially change, the parameters through which we negotiate that world" (2011: 9). Thus, the role of the art practice is to imagine a future state that we cannot anticipate within the restrictions of our world.

Assigning the artist the role to envision another world emphasises the, "ethical and political responsibility" (Meskimmon, 2011:7) of the artist and brings back the old debates about the artists as the committed figure within the realm of politics. With these discussions at the forefront, Hal Foster opens his 1996 dated essay, “Artist as Ethnographer". Building upon Walter Benjamin's arguments about artist as producer, Foster questions the tumultuous liaison between art and politics, and consequently the role and work of the artists within society.

Okwui Enwezor marks as the center of Benjamin's essay the "question of the artist's or writer's commitment under certain social conditions" (Enwezor, 2004: 1). A question that is very much relevant today, nevertheless, the current shift in the scope of politics affects the parameters we analyse the relationship between art and politics, the conditions determining artist's commitment. "[A]rt and politics are now much more broadly concerned with conditions of social life", as we can see in artists engagement with issues concerning "the environment, human rights, globalization, racism, nationalism and social justice" becoming the focus of politics and art (Enwezor, 2008: 76). This changing field of politics also results in the shifting subject of association in politically engaged art. While Hal Foster locates the artist within the field of culture, as a cultural actor dealing with the, "cultural and/or ethnic other", Benjamin had the artist who, "side[s] with the proletariat" in mind (Benjamin in Foster, 1996: 302). Now it is the cultural, ethnic Other that artists identify with, which structurally follows, "the old 'author as producer' model" and marks a paradigmatic shift, which Foster calls, "the ethnographic turn" in art (1996: 172).

\section{A BRIEF HISTORY OF PERCEPTION OF SPACE IN ART, TOWARDS THE ETHNOGRAPHIC TURN}

As the world we inhabit increasingly is "marked by movement, change and multiplicity" (Meskimmon, 2011: 5), the subject the artist becomes concerned with is the exile, refugee, nomad, the diasporic and the migrant. These voluntary and involuntary characters of displacement are the figures of a world where geographies of home are disrupted; a world in which the meaning of place, the practices we employ to remain in place, are challenged. This is a field of inquiry that artists share with the practitioners of ethnography, since they both show an interest in, "understanding...the one world we all inhabit" (Ingold, 2011: 229) in their own distinctive ways. A key methodology in anthropology (as well as in other social sciences e.g. cultural geography), ethnography entails, set of methods through which the researcher engages in people's everyday lives: observing, participating, recording and collecting as much data as possible to tease out the research subject studied (Hammersley \& Atkinson, 1983: 1). Ethnographic study employs research techniques that range from participant observation to surveys, censuses, interviews and life histories that facilitate the gathering of information (Llobera, 2003). The empirical data collected through this research is then translated into the final monograph into a written analysis of the field.

In its traditional sense, ethnographic inquiry requires a direct engagement with the field of study. The quintessential method of ethnography, fieldwork, epitomises this emphasis on firsthand experience and demands spending a lengthy period of time on a particular site, familiarising oneself with the Submit Date: 15.04.2019, Acceptance Date: 20.06.2019, DOI NO: 10.7456/10904100/002 
everyday practices of the others. As Nigel Rapport indicates, the outcome of this study takes the form of, "final writing of coherent reflections and analyses, facilitating a later retrieval of overall sense and order" (1997: 94). The process of writing up entails interpretation of the experience of the fieldworker at the field in the form of written text within ethnographic monograph that provides a realistic narrative of the field.

As the founding principles and the conventions of discipline of anthropology were disputed and subverted, the limits of ethnography and the role of its practitioners also become the centre of some heated debates. Anthropologist George E. Marcus states that around the time the disciplinary boundaries and responsibilities of anthropology were questioned while the postcolonial discourse cast a critical eye upon the conventions of the anthropological mind, the art world also began to show an increasing interest in the realm of the social, as evidenced by the soaring number of socially conscious artworks being produced (Marcus, 2008: 36). Thus, anthropologists' concern with the study of social culture overlapped with a moment in art, when artists put particular focus on exploring this very same field. The unique manners of artistic and ethnographic inquiries work on this mutual field of interest, hence the practices, tropes and disciplinary presumptions that define the conventions of the ethnographic method are reinterpreted to the extent that novel forms of inquiry have emerged across the dialogue between art and ethnography.

Miwon Kwon defined the shift that led to the emergence of the "socially conscious artwork" (Marcus, 2008: 36) as a "discursive" moment in art, the genealogy of which she traces back to the minimalism. Kwon emphasises the "phenomenological and experiential" character of the minimalist space, which focuses on, "the actual physical attributes of a location" (2004: 3). This particular understanding of space continued in the notion of site-specific work, which was concerned with the institutions of art and its impacts on the presentation, perception and, inevitably, the production of art. While in its early stages the focal point of site-specificity was art institutions, later this scope has broadened when the meaning of "site" was expanded to include non-art realms. The presence of a work of art was no longer considered to be limited within the physical constraints of the exhibition space (Bois et al., 2005: 624). The institutional framework of art was actually formed by a network of other discourses determined by social and political agendas.

Soon, as Foster succinctly indicated, "the institution of art could no longer be described only in spatial terms (studio, gallery, museum, and so on); it was also a discursive network of different practices and institutions, other subjectivities and communities" (1996: 184). This analysis in itself can be considered within the "mobility turn" in contemporary social thought that marks a shift in the way we think about space. Within this perspective, space is defined as the network of relations and the flows in interaction, rather than suggesting a fixed, static location. Similarly, the discursive understanding of art marked the perception of site as contingent to, "much broader cultural, social and discursive fields, and organized intertextually", as Miwon Kwon argues (2004: 3). Site-specific art was considered the prominent form in institutional critique, marking a shift of focus from the work towards its surrounding site, and the acknowledgement of what Kwon called the "discursive turn": the dependency of artwork on wider social, economic and cultural parameters.

In this lineage, the site slipped away, "from the surface of the medium to the space of the museum, from institutional frames to discursive networks" (Foster, 1996: 184). Thus, the site of art extends, "across much broader cultural, social, and discursive fields" (Kwon, 2004: 3) and progresses beyond familiar art contexts. The axis of art practice has shifted from a medium specific practice into a discourse specific one (Foster, 1996: 184). Instead of the problems intrinsic to the art discipline, an undisciplined movement, "from social issue to issue, from political debate to debate" began to dominate contemporary art production, which marks the so-called "ethnographic turn" in art (Foster, 1996: 199).

Submit Date: 15.04.2019, Acceptance Date: 20.06.2019, DOI NO: 10.7456/10904100/002 
As the site of art began to converge with that of ethnography, artists and ethnographers began to show a deeper curiosity about one another's endeavors. Considered as a "science of alterity" (Foster, 1996: 182), anthropology seemed to offer the means to access the field of cultural inquiry. Consequently, its methods began to be widely appropriated by artists who worked within the expanded site of art. The shape of artistic production was again changing, and accordingly, questions about the work and role of the artist became the subject of discussion, this time in relation to the 'artist-ethnographer' paradigm.

Nonetheless, Hal Foster indicated his concerns about the use of ethnographic methods of anthropology as a magical formula in the study of culture. The, "Artist as ethnographer...draw[s] indirectly on basic principles of the participant-observer tradition" or other seemingly ethnographic methods like inventories, questionnaires and some documentary strategies (Foster, 1996: 181). Its methods can, however, be appropriated without questioning the problems inherent in ethnographic work, which may result in, "pseudo-ethnographies" or, "testimonies of the new empathetic intellectual" or, "traumatic, confessional" accounts (Foster, 1996: 180). The mere replication of ethnographic methods not only risks producing meagre ethnographies but it also restricts the emergence of possibilities across the distinctive practices of inquiry. Instead, this limited model of artist as ethnographer should be explored and expanded further. For that very purpose, the conversation between art and ethnography should be located on a transdisciplinary ground, beyond the restrictions of disciplinary boundaries. This will shift the focus from methodological disparities and mimicries towards the shared concerns of art and ethnography.

\section{THE DECLINE OF DOCUMENTARY LANGUAGE IN ETHNOGRAPHY AND THE EMERGENCE OF SUBJECTIVE VOICES IN THE STUDY OF CULTURE}

A reconceptualisation of ethnography that challenges the conventions of documentary procedures and the realistic paradigm at the heart of ethnographic research proved to be necessary for expanding the conversation between art and ethnography. In Tim Ingold's definition of graphy as the primary activity defining ethnographic research, the purpose of ethnography as writing about people and culture is given a new turn. Ingold indicates that the act of graphy is not constrained to writing and "finding the right words to record or convey what has been observed" (2007: 128). Similarly, anthropologist Edward Bruner recognises the limitations of anthropological work and considers it as a mode of representation of reality $(1986: 16)$. Bruner establishes his argument upon the incommensurable, "gaps between reality, experience, and expressions" (1986: 7). There is no form of representation that could capture the lived experience unproblematically (Denzin, 1997: 3), validating the 'unruly' manners of artistic expression as relevant in the study of lived experience, a field of interest both ethnographers and artists share (see Oskay, 2014: 48).

With the decline in the, "distinctive documentary function" of ethnography (Marcus, 2010: 86), the documentary language that overwhelms the ethnographic work also obliterates. The methods of traditional documentary that manifest in the, "gathering of 'facts', the careful preservation of imperilled folkways, the construction of arguments through demonstrative proofs" (Renov, 2004: 171) lose their unshaken authority in ethnographic work. As the objectivist basis behind the documentary modality becomes undermined, the neutral, impartial observer in the field is dethroned and the distinctions between subject and object of study are blurred. Within the field of anthropology, this shift corresponds to the reflexive turn, which openly questions the claims for objective truth and unbiased representations of the field. Instead of claiming to reveal the truth, the emphasis on the subjectivity of the experience focuses on, "detailing concrete experience and multiple perspectives that include participant's voices and interpretations", as Carolyn Ellis argues (2004: 29). The singular, subjective voices defy the epistemology of ethnographic inquiry that risks characterizing individual subjects as, "representative of cultural practices and even 'human' principles" (Russel, 1999: 5), thus diminishing the complexity of reality into abstract generalizations.

Submit Date: 15.04.2019, Acceptance Date: 20.06.2019, DOI NO: 10.7456/10904100/002

Research Article - This article was checked by Turnitin

Copyright (C) The Turkish Online Journal of Design, Art and Communication 
In contemporary art practices, T.J. Demos marks a similar tendency in, "subjectively reflexive narratives" (2009: 84), concerned with expressing experience without the risk of objectifying the studied subjects. In this regard, autoethnography as a means to study the cultural through the personal, as "a particular perspective on knowledge and scholarship" (Denzin, 2008: 374) which values the knowledge and experience of the self in inquiry becomes a subfield to analyse the common ground between the "subjectively reflexive" art practices. Autoethnography emerged as one of the means of studying culture that came with the recognition of researcher's presence in the scene of research. As a result, personal stories and knowledge have begun to be considered as a possible means to study the culture and human behavior as well. Self-knowledge become "a central source of data... becoming another acceptable scholarly basis for understanding social life and human behavior" for social research Rosanne Hertz suggests (1997: ix- xii). The personal becomes the base for theoretical, Nancy Miller argues, a valid "cultural material", in the inquiry of the social (1997: 21). This idea of "personal as theoretical" resonates with the feminist coda of "personal is political" that has been embraced in the art of $70 \mathrm{~s}$, where artists from the margins of society take the stages of cultural production. The presence of these marginalized selves become "crucial medium for resistance and counter discourse" that cast "doubt on the coherence and power of an exclusive historiography" (Renov, 2004: vi). As visual anthropologist David MacDougal suggests succinctly, in the discipline of anthropology "a single ethnographic reality, only waiting for anthropology to describe it" (in Russell, 1999: 12) has lost its ground and the discipline opened itself to "different histories" (Clifford in Russell, 1999: 5). The once erratic personal source becomes the source for knowledge, where theory and knowledge has gone through substantial change of status, where the limits of social research has broadly expanded thanks to the postcolonial and feminist epistemologies.

This insight, through "detailing concrete experience and multiple perspectives that include participant's voices and interpretations" can be an alternative to privileging "theory generation, typicality, and generalization" Carolyn Ellis argues (2004: 29). The singular voices can disrupt the conventional course of knowledge production in conventional ethnography which Catherine Russell describes as a process "by which individuals are abstracted into general social patterns; individual subjects become representative of cultural practices and even 'human' principles" (1999: 5). In the following section, selected works addressing the complex feel of displacement from a personal perspective will be analysed, in order to expand the discussions on the crossover between ethnographic practices in the field of art. To this end, a close look into the artistic strategies will allow us to explore how the effects of displacement are reflected in the works of Jonas Mekas, Marcel Duchamp, Mona Hatoum and Zarina Hashmi.

\section{CASE STUDIES: THE SUBJECTIVE VOICES OF DISPLACEMENT IN ART:}

\section{Jonas Mekas: The Order of Life in Dispossession}

Jonas Mekas' filming career starts with a borrowed camera in the United States, after he left his home in Lithuania. Having been an avid diary keeper before his forced leave from his homeland, he developed a habit of recording his life on the medium of film. For Mekas his films are a continuation of his diary-keeping habit. He would carry his camera everywhere, just as he would his diary, a habit that has become a central practice in his work: "All my personal work became like notes...I thought what I was actually doing was practicing. I was preparing myself, or trying to keep in touch with my camera, so that when the day would come when I'll have time, then I would make a "real" film" (Mekas in James, 1992: 149). 
As David James argues, "photographing the fragments of his own life was his practice of film" (1992: 149). Mekas films for keeping a record of his life, as a way of responding and relating to his immediate surroundings as well as a means of proving his existence, here and now. Yet, beyond these more personal motivations in his works, Mekas accomplishes to give his audience a detailed insight on the reality of the exilic experience. In that sense, Catherine Russell categorises his work as prototypical autoethnographic film, where the, "the film medium mediates between individual and social histories" (1999: 281). Mekas' response to his personal dilemma contributes into unravelling the conditions of the exilic state in a wider context besides fulfilling a personal exigency.

Film diaries and diary films constitute two main stages of Mekas' working process. As David James states, "the former is Jonas Mekas' personal record of his life, begun only months after his arrival in the United States and continuing up to the present...left unedited for longer or shorter periods of time" (James in Horak, 2010). Lost Lost Lost (1976), one of the very first diary films, fourteen years of his life after his arrival in the States, after he had flown from his homeland, Lithuania is recorded. The diverse moments of Mekas' life recorded on the film reels (following many unexpected trajectories as it entangled with the lives of others) lay untouched until 1976, when Mekas eventually edited them. The challenge for Mekas was to give an order to his life collected on these reels. In one of his diary films, As I was moving ahead, occasionally I saw brief glimpses of beauty, Jonas Mekas expresses the challenge of ordering and narrating this autobiographical material:

I have never been able really to figure out where my life begins and where it ends...when I begin now to put all this tolls of film together to string them together...the first idea was to keep them chronologically...but then I gave up ...then I begun splicing them together by chance...the way I found them on the shelf...because I really don't know where any piece of my life really belongs. So let it be, let it go...by pure chance...disorder...there is some kind of order ...order of its own...which I do not really understand same as I never understood life... and I do not want to understand them (in As I was moving ahead, occasionally I saw brief glimpses of beauty, 2000).

Perhaps due to a need to reorient himself within the unfamiliarity of his new dwelling, the urgent need to grasp what is happening around his immediate surrounding has revealed itself as a desire to capture what is happening 'here and now'. As a result, he is left with an excessive amount of filmed material, which brings a question of how to translate all these, "disparate images into an autobiographical narrative" (Horak, 2010: 57). David James highlights the different temporalities inherent in these two distinctive moments at work in Mekas' practice. He writes: "Where the film diary was constrained within the present of immediate perception...the diary film confronts its own present with the assembled fragments of a time now lost, of loss itself, of a past that can neither ontologically nor filmically be "presented"" (in Horak, 2010: 57). This is an attempt to negotiate these two distinctive moments in his practice that reflects the realities of his life as an exile, as a displaced person who has lost the familiarity of home and lives with the fear of losing everything once again. In between these two temporalities, we see glimpses of a displaced life torn between a desire to hold onto now and the past that sticks onto the present.

We hear Mekas speaking over the images we see on the screen, reflecting on the scenes from his collections, yet not necessarily describing or explaining to us what we see. Like home videos, which we shoot and only watch at a much later stage, Mekas was perhaps seeing what he recorded for the first time when he began editing. We hear him thinking about his life retrospectively. The act of editing triggers the question of how the different moments of his life are tied to one another, how the past relates to the present, how exactly contrapuntal temporalities exist on the horizon of an exile. The excessively fragmented imagery gathered in these films parallels the sense of loss he found himself

Submit Date: 15.04.2019, Acceptance Date: 20.06.2019, DOI NO: 10.7456/10904100/002 
amidst. Mekas aspires to pack all the bits and pieces of a life in the limited time the film allows. His films appear as a massive collection of images that collapse in upon each other. In this sense, his practice becomes a way of wresting his life back from the curse of dispossession through continuously collecting his present time.

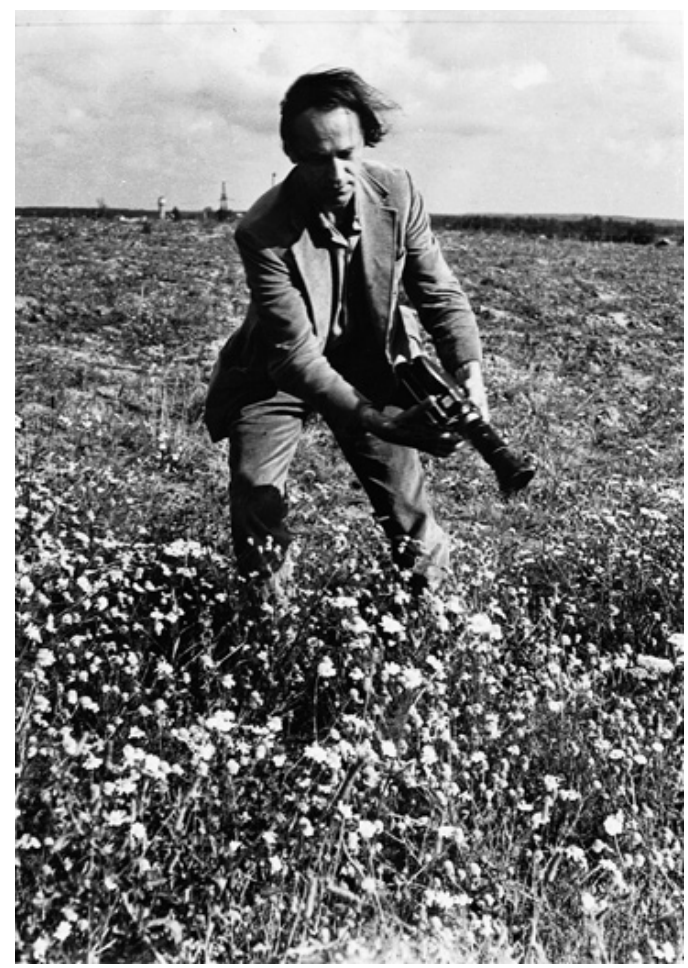

Figure 1. Mekas with his camera while filming, 1971 (Mekas, 1971).

His filming technique, similarly addresses this overwhelming feeling of dispossession. While filming, Mekas does not necessarily look through the camera's viewfinder. He rather moves with his camera, never knowing what he has filmed until he watches the recordings. His bodily movements are imprinted on the images we are seeing. In this sense the recordings are closer to the materiality of trace carrying the mark of Mekas' presence. As we see in the Figure 3, he is more like collecting the flowers from the field rather than capturing their images on film. Mekas does not seem to be too much concerned with capturing a legible recording; the information collected on the film is secondary. Rather than the camera slowing down the movements of Mekas, it is the camera that is subject to Mekas' movements, Mekas' presence. Thus, the recorded material, the temporality of recording becomes subservient to the experience.

Owing to this approach to filming, the unruly transitions from one point to another create restless movements on the screen. Sometimes the images in a Mekas' movie pass at such a speed that all the images dissolve into one another, creating a difficult viewing experience. The pace of the appearance and disappearance of the images on the screen is so fast, the scenes replace one another at such a speed, the audience is left with a feeling of motion sickness. The images on the screen replace one another so swiftly that the limits of the figures on the screen blur. The movement renders the images, the fragments of his life unidentifiable and poses a question about identity in movement. A sequence of colours, constantly shifting patches of colour, a flickering light rather than any identifiable narrative or any recognisable reference points, any place of rest fills the screen. The experience of watching the material was an uncomfortable one. This refusal to stop on any image is expressed in his filmic technique, which Catherine Russell calls a, "technique of homelessness", which corresponds to 
Mekas' personal experience of homelessness (Russell, 1999: 282). The resulting disrupted narratives in Mekas' works reify the hesitant, indeterminate feeling of dwelling in-between.

\section{Marcel Duchamp: Box in a Valise}

In Marcel Duchamp's Box in a Valise (1935-41), it is the threat of dispersion in the face of displacement that led him to collect his life work in order. T.J. Demos' (2007) reading of Box in a Valise uncovers the links between the tentative form of Duchamp's box, the alternative order employed in the organization of the works that defies any logic of categorization and his expatriation. The work stands as a response to the rigid, patriotic notion of identity engulfing during the two World Wars, by proposing a subject, a body (of work) under continuous construction that subverts any static forms of representation. The exigency of escaping from the clearly demarcated borders of identity manifests itself once again in the shared authorship of the Valise with his female alter ego, Rrose Selavy, which accentuates Duchamp's determination to break away from any prescribed categories.

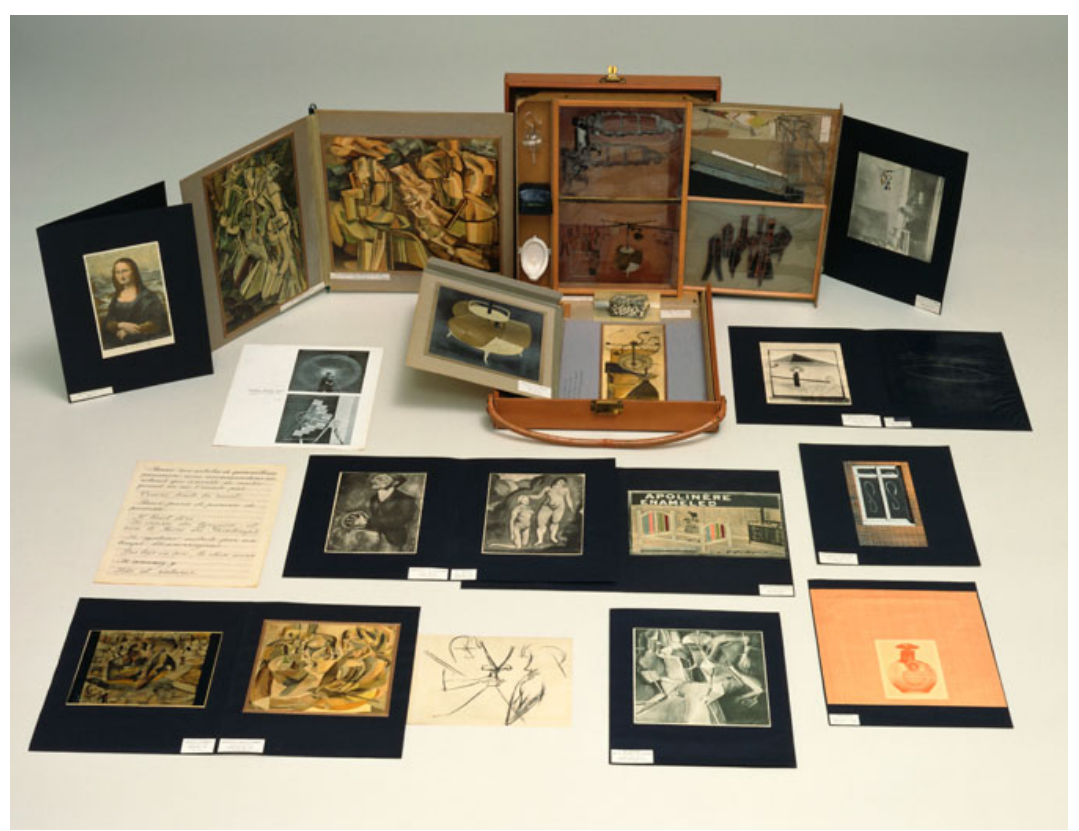

Figure 2. Box in a Valise, 1935-1941 (Duchamp, 1935-1941a).

Duchamp's Box contains photographic images of his work cut out from the magazines, black and white reproductions of his works hand-coloured using a pochoir technique, and three-dimensional miniature replicas of his readymades in a peculiar order. Jerrold Seigel remarks this chaotic order that defies any logic of classification: "Putting so many works and objects inside such a casing called attention to the question of how they were all related to one another" (Seigel, 1995: 232). Duchamp offers an unstable, tentative collection in his portable museum to be continuously rewritten, reconstructed and circulated. 


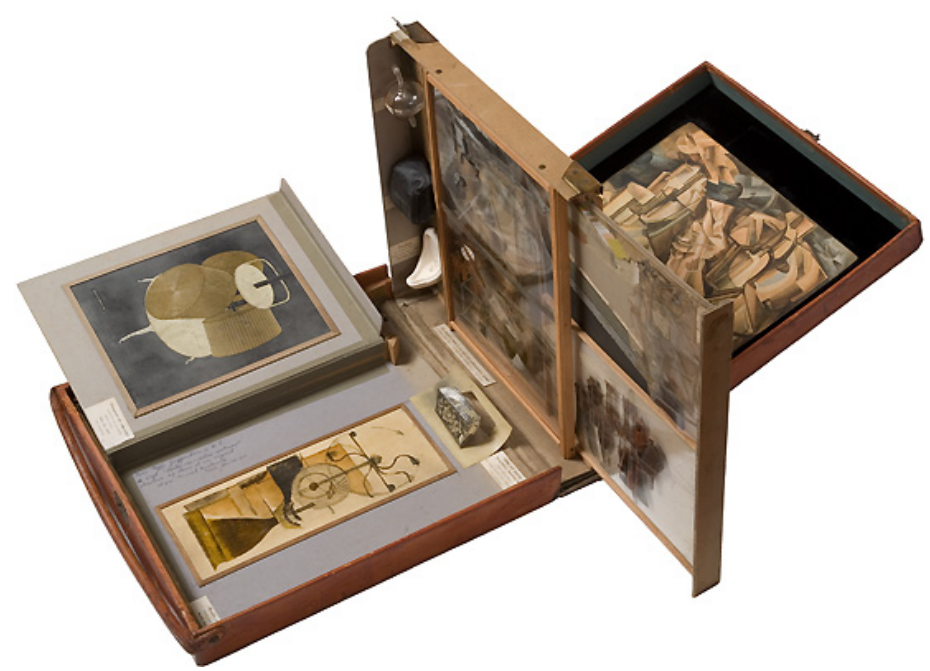

Figure 3. Box in a Valise (From or by Marcel Duchamp or Rrose Sélavy) (Duchamp, 1935-1941b).

When Duchamp began the preliminary sketches of the box in 1935, he was preparing to leave war-torn Europe, the foundation of, "the entire 'homeland' of Europe, as the secure house of western civilization" was shattering (Vidler, 1992: 4). This was a time when the achievement of the western culture was cast in doubt with the violence spreading across the continent. The conditions of war consequently led to, "a powerful disillusionment with the universal 'museum' of the European 'fatherland"" (Vidler, 1992: 4). The mobile structure of Duchamp's collection suggests the desire to escape from the rigid structures, of not only the institutional frameworks of museums (that fixed his oeuvre under certain categories), but also from the suffocating borders of Europe that left no room for the Other. Against the backdrop of the time where an oppressive sense of, "essentialised communal identity" reigned, this project could also be considered as a reaction to a xenophobic notion of identity (Demos, 2007: 42). Duchamp was seeking to, "reconstitut[e] a sense of self" (Demos, 2007: 42), an itinerant, unstable, provisional self that is open to the Other, by inviting this Other into its making, while all across the world strict boundaries were demarcated hostile to the ones who do not belong to 'us'.

Box in a Valise also goes under the name From or by Marcel Duchamp or Rrose Selavy. This collaboration not only unsettles the authority of the single author but it also contributes to undoing the clearly drawn boundaries of the subject. Duchamp donned Rrose Selavy (once again) to decentre the conception of essentialised identity. By embracing his 'Other', Rrose Selavy, as the co-author of this Box in a Valise he unsettles the body of Duchamp. Against the suffocatingly rigid notion of identity he assumes a female alter ego, and thus, erodes, "the stability and coherence of his own identity" (Seigel, 1995: 119). Demos observes that, with an aspiration to escape from the patriotic notions of identity of the time, in this way, Duchamp proposed a different notion of subjectivity, "that freed itself from the strictures of an increasingly claustrophobic national identity" (2007: 21).

In this regard, the Valise manifests the exigencies of an exilic identity, a life, "between a dispersion that placed the very coherence of the self in jeopardy and a compensatory urge that tempted a suicidal self-embalming" (Demos, 2007: 20). As if in preparation for Duchamp's escape from Europe, the reproductions of his life works sit in a valise, ready to travel with him. In the compact form of the suitcase, Duchamp gathers his body (of work). He poses the multiple and itinerant nature of the self against a divided world that grows more and more hostile to its others. Thus, he turns the work of selfrepresentation into a relentless self-construction. 


\section{Mona Hatoum: The Interior Landscape of Displacement}

In Mona Hatoum's work the disorienting impact of displacement is expressed through the everyday objects that surrounds, furnishes and supports the body. Hatoum's strategy of transforming the everyday objects into their threatening, unhomely counterparts reflects the state of an in-between dwelling that shakes the foundations of the taken for granted everyday reality.

The duality between familiar and unfamiliar, the homely and strange implies an uneasy encounter, a coexistence that characterises the experience of the displaced, for whom home is a problematic site. The double nature of Hatoum's works arises an uncanny feeling, which reveals a presence caught inbetween, amidst a contrapuntal state.

In the transformation of the mundane façade of everyday world Hatoum's displacement expresses itself materially. "We usually expect furniture to be about giving support and comfort to the body", she remarks, and turns this comforting feeling into an uncomfortable, disorienting experience (1998: 7). By rendering these objects of support as "either unstable or threatening" (Hatoum in conversation with Antoni \& Hatoum, 1998: 7), Hatoum disturbs the notion of home as a place of peace and stability, as a safe haven. The outlandish feeling of displacement distils strangeness into these objects. In Hatoum's works Edward Said finds an unbearable scene, "full of grotesque structures that bespeak excess as well as paucity" that characterize the world of a refugee (in Müfti, 2011: 174-175). Between this "excess and paucity" Hatoum's work manifests an inability to settle down, in contrast to a feeling of home that defines a moment when everything seems to be in their right place, where nothing strikes as neither superfluous nor scarcity, but just in right order. Hatoum unsettles the mundane objects furnishing the comfort of home through making these objects unidentifiable and inappropriate. These everyday objects retain the character of the irresolute ground they rise on now. The, "sense of instability and restlessness" dominating her works carries the traces of her background (Antoni \& Hatoum, 1998: 4). A study of Mona Hatoum's work inevitably delves into detailing the embattled background, the geography she is coming from. Nonetheless, she expresses her frustration over the generic autobiographical information becoming the sole reference in the analysis of her works:

I'm often asked the same question: What in your work comes from your own culture? As if I have a recipe and I can actually isolate the Arab ingredient, the woman ingredient, the Palestinian ingredient. People often expect tidy definitions of otherness, as if identity is something fixed and easily definable (Hatoum in Antoni \& Hatoum, 1998: 1).

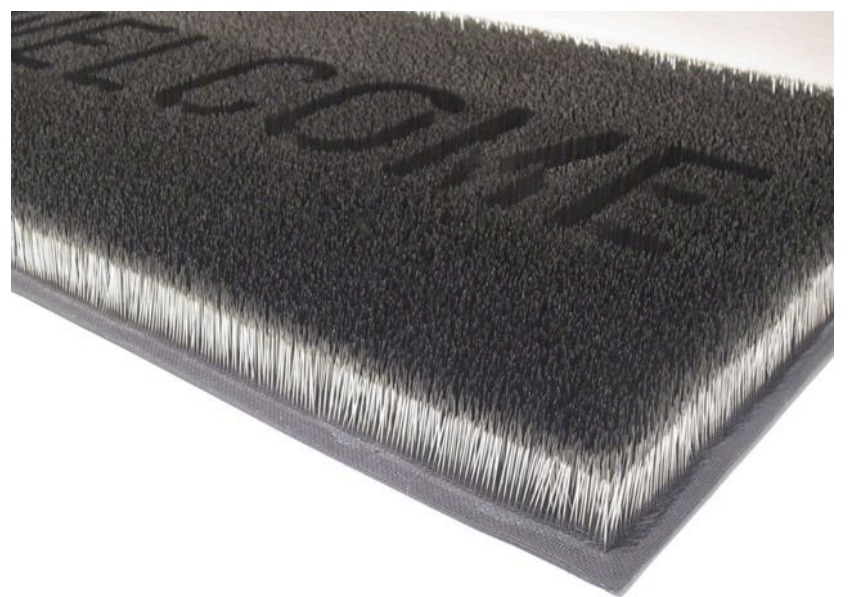

Figure 4. Doormat II, 1996 (Hatoum, 1996).

Submit Date: 15.04.2019, Acceptance Date: 20.06.2019, DOI NO: 10.7456/10904100/002

Research Article - This article was checked by Turnitin 
Hatoum openly displays her discomfort about being confined into the fixed categories of identity and into a fixed geography. This is a common perspective in art criticism that Nicholas Bourriaud calls a "symbolic house arrest", by which, "everyone is located, registered, nailed to a locus of enunciation, locked into the tradition in which he or she was born" (Bourriaud, 2009: 34). On the other hand, Hatoum's work is a question cast on these lines of segregation, on the unjust certainty of borders. She rejects this house arrest that incarcerates her into the stereotypical categories of Otherness, ossifies the frontiers and borders and accordingly increases the gap between self and the other, between 'here' and 'there'. "I find myself often wanting to contradict those expectations", Hatoum states (in Antoni \& Hatoum, 1998: 2). Even though the objective behind such an approach is to give a voice to the minor positions, to better represent the troubled geographies of displacement, it risks ending up in the, "fetishisation of the alterity of the artist from the margin" (Papastergiadis, 2005: 341). In Hatoum's work, the suffocatingly rigid notion of identity that sustains itself through securing cultural, ethnic, gender differences is problematized through continuously revisiting its prescribed boundaries.

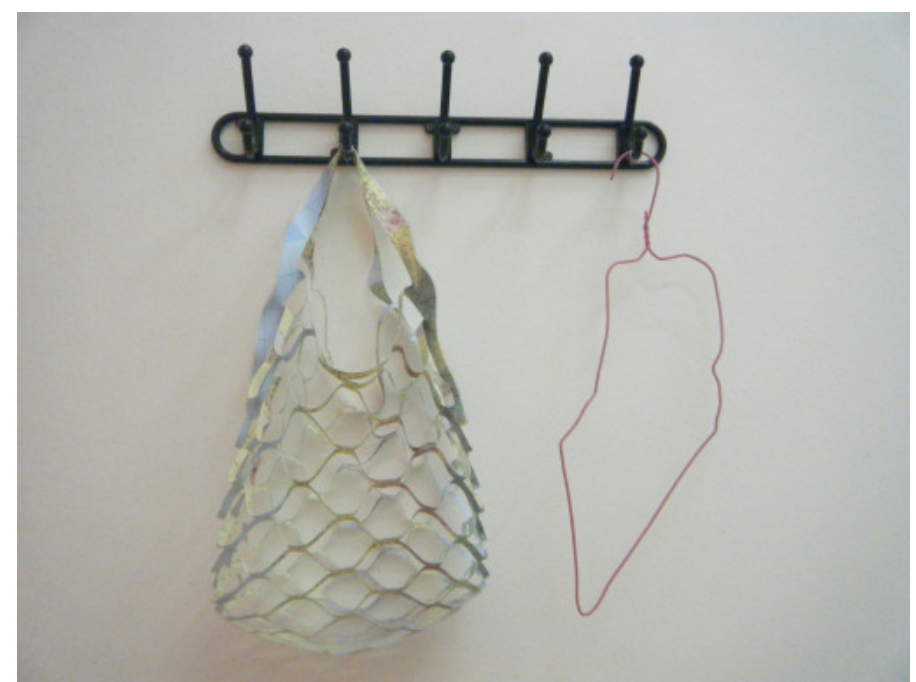

Figure 5. Detail from Interior Landscape, 2008 (Hatoum, 2008).

In her installation Inner Landscape, a detail on the wall particularly manifests this desire to escape from the strictly drawn limits of identity. We see a map of Palestine made by a wire coat hanger on the right and on the left; a disfigured map in the shape of a shopping bag is hung next to it. Both maps are hung on a coat hanger next to the door; suspended in a limbo state at the entrance/exit of a place. Just before entering/leaving one place for another, Hatoum leaves aside the maps that signify a placebound identity, by leaving the borders drawn between 'us' and 'them' at the threshold.

The repeating motive of maps redrawn, cut, disoriented in Hatoum's work underscores her troubled relationship with the geographical location assigned to her identity. Jaleh Mansoor suggests that it is the diasporic character of Hatoum's dwelling that tears apart, "the concreteness of location, of place" (2010: 60). Hatoum dismembers the maps that fix her identity within their rigid clusters. The abstract lines of maps are far from capturing the complex reality of a dwelling in-between that defies borders. At odds with the clearly defined boundaries of identity, this is a state of being that, "dismantle[s] categories" (Mansoor, 2010: 61) and overrules the possibility of solid, stable ground.

"Can we assign stable attributes to experience that imply the falling away of any permanent ground of signification and representation?" asks Aamir Mufti (2011: 175). His question concerns representations of homelessness, of displacement; an experience that uproots the belief in a solid

Submit Date: 15.04.2019, Acceptance Date: 20.06.2019, DOI NO: 10.7456/10904100/002 
ground established by the obvious, habitual order of home. Hatoum responds to this slowly disintegrating ground of home by dissolving the familiar façade of the everyday world that we take for granted. She responds to this crisis of representation and signification in the falling apart of stable anchor points to hold onto in her work.

\section{Zarina Hashmi: Revisiting Home}

In Zarina Hashmi's work the boundaries of home are similarly revisited in order to locate the disorienting feeling that comes with arrival in a new, unfamiliar place. In her print series that dates back to 1999, entitled Home is a Foreign Place, she imprints her childhood home in India in fragments, in an abstract and formal language. Runa Samantrai suggests that Hashmi finds a solace against the unsettling forces of movement, "a life that has moved in many directions... a world so complicated that it borders on chaos" (2004: 174) in her formal, overwhelmingly symmetrical compositions. In symmetry she finds an order that consoles her need to, "keep a centre" (in Samantrai, 2004: 174). The demand for stability against the pre-eminent feeling of disorientation manifests itself in the perfectly balanced plans of her prints.

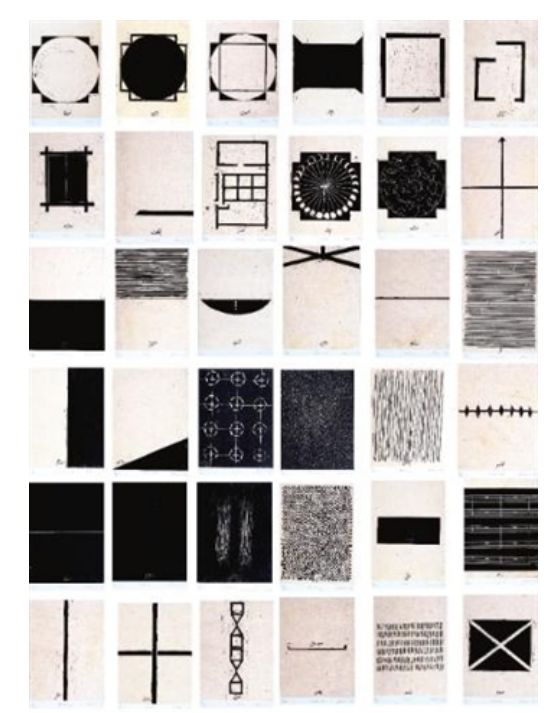

Figure 6. Home is a Foreign Place, 1999 (Hashmi, 1999).

The introduction of the house motif into Zarina Hashmi's works emerges when this feeling of disorientation intensifies. "I started to wonder where I was, where I had come from, how I came to be standing by myself in that desert, encircled by horizons" (Hashmi in Samantrai, 2004: 174). Recalling a moment when she found herself in the middle of a desert that demands fundamentally distinctive means of navigation, Hashmi felt at a loss. Without any familiar reference points to orientate herself, she was surrendered by the vastness of the unknown, by the unruly possibilities of new horizons. Her preoccupation with the house motif comes at this point, as the feeling at a loss brought an urgent need to relocate herself within this outlandish space. "I came to it [the house motif] when I needed to put my life in order", Hashmi says. "It allowed me to situate myself after I had left the known path laid out for my life and struck out on my own" (in Samantrai, 2004: 177). Hashmi deals with the unsettling impact of dwelling within this completely different spatial order, through reinscribing her home on the blank, deserted surface of the paper. Home is a Foreign Place contains 36 prints that depict the physical structures of the house she grew up in, as well as the immaterial qualities of the home. The titles of the prints in the series give us clues about different aspects of her childhood home as it is contemplated in close up in these fragments. The concrete materiality of Threshold, Border, Entrance, Courtyard, Wall joins into the immaterial states that is less inclined to give themselves to Submit Date: 15.04.2019, Acceptance Date: 20.06.2019, DOI NO: 10.7456/10904100/002 
representation, like Distance, Time, Country, Despair, Journey, Language etc. These are the multifarious details that inhabit her memories, when she imagines her home she left behind in India, in her childhood.

In another series of prints, Homes I made/A Life in Nine Lines (1997), she draws the floor plans of the interior spaces of the homes she stayed in different cities, in the abstract, impersonal language of architectural plan drawings. She imagines her place within the many places she trespassed, crossed and left behind, the many horizons that she was surrounded by. Aamir Müfti defines Hashmi's work as, "place-images...images of places", as much as, "images about the imaging of these places" (2011: 188). The detailed look in Home is a Foreign Place is lost this time with the elevated view from above, which evokes a sense of distance. The distinctive perspectives in these prints manifest the different manners of dwelling that mark Hashmi's life story. While in her previous prints she imagines her home in India with a sense of intimacy, in her later works she strives to capture the concrete essence of the idea of home, and shifts her focus from her unsettled, disoriented life.

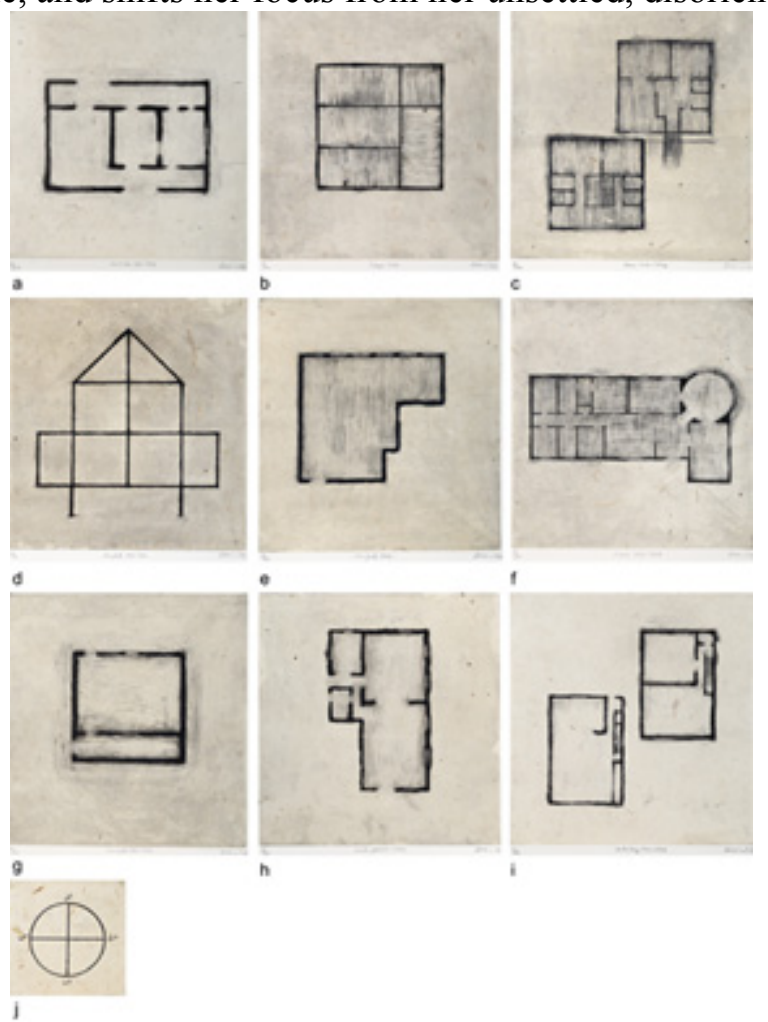

Figure 7. Homes I made/A Life in Nine Lines, 1997 (Hashmi, 1997).

\section{CONCLUSION: THE AESTHETICS OF DISPLACEMENT}

In the figures of the exile, diasporic, expatriate, newcomer, latecomer and stranger, we observe a journey that leaves the familiarity of home. It is an experience disrupting the routine ways we dwell in the world. The coexistence of different stories, different orders and temporalities unsettles the familiarity of home through distinctive personal accounts of displacement in the selected case studies. The singular voices in these case studies offer experimental forms of working in the field of culture, which has the potential for, "push[ing] the boundaries of prescribed ways of conducting social science", as Rosanna Hertz suggests in relation to the reflexive methods in ethnography (1997: xii). In that sense, the conversation between art and ethnography offers an area to explore this possibility, to transform the conventional course of knowledge production in traditional ethnography. Artistic forms 
of inquiry reminds us the imaginative aspects of the research, which Michael Taussig argues to be muted by the hard science of collecting data (2009), by the strategies of documenting, recording and describing. With the language of "imaginative speculation" (that Amanda Ravetz argues to be distinguishing art from the ethnographic practice) these works revive the long neglected aspect of the inquiry, that of "imaginative discovery" (Taussig, 2009).

Although the working methods of each artist vary, what is common is the taking off from the personal experience and rendering their individual concerns into a form of expression not necessarily textual, descriptive, documentary, as it is with the conventional ethnography. In the expanded field across ethnography and art, these works move beyond the methodological conventions and employ, "imaginative techniques" of art (Ravetz, 2009).

In the relentless acts of recording, collecting and ordering his life story imprinted on film, we encounter the exigency of dispossession that comes with an exile in Mekas' practice. The mobile structure of Duchamp's valise calls its audience to reorder his body of work, construct a different body of Duchamp that consequently defies strict limits of identity within a xenophobic war-torn world. The disoriented everyday objects within the domestic spaces of Hatoum show us the unsettled, uncanny boundaries of home in displacement. In the strictly balanced compositions of Zarina Hashmi's images of home, we witness how a desire to centre, balance oneself amidst the disorientation in the unknown is expressed. The examples discussed here give insights about the everyday reality of displacement, how our dwelling is infected by different orders of movement that collapse here and there, home and away, familiar and unfamiliar, then and now, self and other upon each other.

Jonas Mekas' response to a life in exile, in utter loss away from his home country appears as a relentless desire for collecting, documenting and reordering his life recorded on film wheels. The ordering and reordering process at work in Duchamp's collection of the replicas of his works manifests a reaction against a static, stagnant notion of identity. We find a related suspicion with the clearly drawn borders of identity in Mona Hatoum's discontent with the "symbolic house arrest" (Bourriaud, 2009c: 34). Hatoum's undone, unidentifiable maps left at suspension are similarly a reaction to this confining sense of home. Likewise, the dismantling and dispersion of the familiar universe of home in unsettling arrangements of the familiar household items and rendering them unidentifiable through symmetrical abstractions manifests similar concerns. A desire to keep a centre in Zarina Hashmi's prints depict different aspects of a home now left behind in Home is a Foreign Place.

The way the works are processed display the diversity of responses to the study of the cultural through personal; to the basic definition of autoethnography. The artists' study of the field of displacement that surround, surrender their existence bring us closer to the actualities of that state of being unsettled by displacement. In contrast to a theorization of the field that provides a general view of the subject by excluding details that cannot be assimilated into a coherent narrative; these individual details provide us other perspectives. In comparison to a view from a distance, the works manifest what an autoethnographic approach to inquiry aspires to do: to capture the particularities, multiplicities and conflicts in the field. We are provided multiple access points to enter into the realm of displacement. These personal expressions have the power to refract the experiences of others, in a similar line with an autoethnographic approach that takes the self as a source of knowledge, as a tool of inquiry and as a medium of expression.

\section{REFERENCES}

Antoni, Janine \& Hatoum, Mona (1998)."Mona Hatoum by Janine Antoni”. BOMB Magazine, 63. Retrieved from: http://bombmagazine.org/article/2130/mona-hatoum. Accessed on 30 January 2014.

Submit Date: 15.04.2019, Acceptance Date: 20.06.2019, DOI NO: 10.7456/10904100/002 
Bois, Yves., Buchloch, Benjamin., Foster, Hal., Joselit, David. \& Krauss, Rosalind. (2004). Art since 1900: modernism, antimodernism, postmodernism. New York: Thames \& Hudson.

Bourriaud, Nicholas. (2009). The radicant. New York: Lukas \& Sternberg.

Bruner, Edward. (1986). "Experience and its Expressions". In Bruner, E. M., \& Turner, V. W. (eds) The Anthropology of experience. Urbana: University of Illinois Press. pp.3-30.

Demos, T.J. (2007). The Exiles of Marcel Duchamp. Cambridge, Mass.: MIT Press.

Demos, T.J. (2009). “The Ends of Exile: Towards a coming Universality?”. In Bourriaud, N. (Ed) Altermodern : Tate Triennial 2009. London: Tate Publishing. pp.73-85.

Denzin, Norman. (1997). Interpretive ethnography: ethnographic practices for the 21st century. California: Sage.

Duchamp, Marcel. (1935-1941a). Box in a Valise. Retrieved from:

https://www.moma.org/collection/works/80890. Accessed on 08.07.2014.

Duchamp, Marcel. (1935-1941b). Box in a Valise. Retrieved from: http://www.guggenheimvenice.it/inglese/collections/artisti/dettagli/opere_dett.php?id_art=55\&id_opera $=122$. Accessed on 08.07.2014.

Ellis, Carolyn. (2004). The Ethnographic I: A Methodological Novel about Autoethnography. New York: Altamira Press.

Enwezor, Okwui. (2004). "The Artist as Producer in Times of Crisis". Retrieved from: http://www.16beavergroup.org/mtarchive/archives/000839.php. Accessed on 12.04.2012.

Enwezor, Okwui. (2008). "Bio-politics, Human Rights, and the Figure of 'Truth' in Contemporary Art". In Lind, Maria and Steyerl, Hito (Eds) The Green Room: Reconsidering The Documentary and Contemporary Art. Berlin Annandale-on-Hudson, NY, Sternberg Press.

Foster, Hal. (1996). The return of the real: the avant-garde at the end of the century. Cambridge, Mass: MIT Press.

Hammersley, Martyn \& Atkinson, Paul. (1983). Ethnography: principles in practice. London: Routledge.

Hashmi, Zarina. (1997). Homes I madel A life in Nine Lines. Retrieved from: https://www.saffronart.com/auctions/PostWork.aspx?1=13663. Accessed on 13.06.2014.

Hashmi, Zarina. (1999). Home is a foreign Place. Retrieved from: http://www.artnet.com/artists/zarina-hashmi/home-is-a-foreign-place-

RUNyEVFFvEx0fMUb51TmFg2. Accessed on 13.06.2014.

Hatoum, Mona. (1996). Doormat II. Retrieved from: http://mondo-blogo.blogspot.com/2011/10/1stproper-day-in-london.html. Accessed on 2.05.2014.

Hatoum, Mona. (2008). Interior Landscape. Retrieved from:

https://zarahackerman.wordpress.com/2009/08/26/mona-hatoum-interior-landscapes/. Accessed on 2.05.2014.

Hertz, Rosanna. (1997). Reflexivity \& voice. California: Sage Publications.

Horak, Jan Christopher. (2010). "Regarding Mekas: Avant-Garde Film and Audience Subjectivity". Millennium Film Journal. Fall/Winter2010/2011(53).

Ingold, Tim (ed.). (2011). Redrawing anthropology: materials, movements, lines. Farnham: Ashgate.

Ingold, Tim. (2007). Lines: a brief history. London: Routledge.

Submit Date: 15.04.2019, Acceptance Date: 20.06.2019, DOI NO: 10.7456/10904100/002

Research Article - This article was checked by Turnitin 
James, David E. (1992). “Introduction”. In James, D.E. (Ed). To Free The Cinema: Jonas Mekas and The New York Underground. Princeton, N.J., Princeton University Press. pp.3-16.

Kwon, Miwon. (2004). One Place After Another: Site-Specific Art and Locational Identity. Cambridge: MIT Press.

Llobera, Joseph R. (2003). An Invitation To Anthropology: The Structure, Evolution, and Cultural Identity Of Human Societies. New York; Oxford: Berghahn Books.

Mansoor, Jaleh. (2010). “A Spectral Universality: Mona Hatoum's Biopolitics of Abstraction”. October, Summer 2010, No. 133, pp. 49-74.

Marcus, George. (2008). "Contemporary Fieldwork Aesthetics in Art and Anthropology: experiments in Collaboration and Intervention”. In Panourgiá, N., \& Marcus, G. E. (eds). Ethnographica Moralia: Experiments In Interpretive Anthropology. New York: Fordham University Press. pp.29-44.

Marcus, George. (2010). "Affinities: Fieldwork in Anthropology Today and the Ethnographic in Artwork". Between Art and Anthropology: Contemporary Ethnographic Practice (English ed., pp. 8394). Oxford: Berg Publishers.

Mathur, Saloni. (2011). "Introduction”. The Migrant's Time: Rethinking Art History and Diaspora. Williamstown: Yale University Press.

Mekas, Jonas (1971). Retrieved from: http://www.klatmagazine.com/photography/pics-06-jonasmekas/6936/attachment/jonas_films_flowers-press-page. Accessed on 12.08.2014.

Mekas, Jonas. (2000). As I was moving ahead, occasionally I saw brief glimpses of beauty. [Motion Picture]. Retrieved from: https://www.youtube.com/watch? $\mathrm{v}=\mathrm{sWUZzaDAAJ}$. Accessed on 15.09.2012.

Meskimmon, Marsha. (2011). Contemporary Art and The Cosmopolitan Imagination. London: Routledge.

Miller, Nancy. (1997). Getting Personal:Feminist Occasions and Other Autobiographical Acts. New York: Routledge.

Müfti, Amir. (2011). "Zarina Hashmi and the Arts of Dispossession". In The Migrant's Time: Rethinking Art History and Diaspora. Williamstown, Mass.: Sterling and Francine Clark Art Institute. pp.174-195.

Oskay, Harika Esra. (2014). "Across Artistic and Ethnographic Practices: The Study of a CrossDisciplinary Dialogue". The International Journal of Interdisciplinary Cultural Studies. Champaign, Illinois, USA: Common Ground Publishing.

Papastergiadis, Nikos. (2005). "The Limits of Cultural Translation". In Fisher, Jean \& Mosquera, Gerardo (eds.). Over Here: International Perspectives on Art and Culture, Massachusetts: MIT Press.

Papastergiadis, Nikos. (2011). "Cosmopolitanism Assemblages Art”. In Mathur, Saloni (ed.). The Migrant's Time: Rethinking Art History And Diaspora. Williamstown, Mass. New Haven [Conn.], Sterling and Francine.

Rapport, Nigel. (1997). Transcendent Individual: Towards A Literary and Liberal Anthropology. London: Routledge.

Ravetz, Amanda. (2009). "News From Home: Reflections on Fine art and Anthropology". In Grimshaw, Anna, \& Ravetz, Amanda. Visualizing Anthropology. Bristol, UK: Intellect (Kindle Edition).

Renov, Michael. (2004). The Subject of Documentary. Minneapolis: University of Minnesota Press.

Submit Date: 15.04.2019, Acceptance Date: 20.06.2019, DOI NO: 10.7456/10904100/002 
Russell, Catherine. (1999). Experimental Ethnography: The Work of Film in The Age Of Video. Durham, N.C.: Duke University Press.

Samantrai, Ranu. (2004). "Cosmopolitan Cartographies: Art in a Divided World". Meridians, Vol. 4, No. 2, Indiana University Press, pp. 168-194.

Seigel, Jerrold. (1995). The Private Worlds of Marcel Duchamp: Desire, Liberation, and the Self in Modern Culture. Berkeley: University of California Press.

Taussig, Michael (2009). I Swear I Saw This. Anthropologies of the Present. London: University of Chicago Press.

Urry, John. (2000). Sociology Beyond Societies: Mobilities For The Twenty-First Century. London; New York: Routledge.

Vidler, Anthony. (1992). The Architectural Uncanny: Essays In The Modern Unhomely. Cambridge [Mass]: MIT Press. 